\section{Staging stenotic oesophageal tumours: Are CT and/or PET enough? Dilate or not?}

\author{
J. Meenan \\ Guy's and St. Thomas' Hospital, London
}

Introduction

Strictured oesophageal tumours are difficult for patient and physician alike. An inability to use standard equipment freely, concentrates the mind as to what the purpose of staging is: what information is sought and why?

Long-term survival with oesophageal and proximal gastric tumours is poor and treatment options for locally advanced disease, unsatisfactory. The scramble for incremental improvements in survival results in a large variation in practice, particularly in respect of using neoadjuvant chemotherapy. Disagreement over general management strategy is both reflected in and moulds discussion on how the staging of stenotic lesions might be achieved. First, to address some of the important peripheral issues.

\section{General considerations}

Surgery confers a survival advantage on those with resectable lesions [1,2]. Neoadjuvant chemotherapy might confer a survival

Correspondence: Dr. John Meenan · Department of Gastroenterology · 1st Floor College House · St. Thomas' Hospital · Lambeth Palace Road · London Se1 7EH · Fax: +44 $2071882484 \cdot$ E-mail: john.meenan@gstt.nhs.uk

Bibliography: Endoscopy 2006; 38 (S1): S8-S12 @ Georg Thieme Verlag KG Stuttgart · New York · ISSN 0013-726X · DOI 10.1055/s-2006-946643 advantage, particularly on those who show a clinical response; equally, those with residual positive nodes fare poorly [3,4]. Although the type of cancer under consideration, adenocarcinoma or squamous cell, does not seem to have much impact on survival, the site of the lesion may; the Siewert classification identifies diseases with different prognoses, junctional (Type II) lesions being more associated with node-positive disease and a poorer prognosis $[5,6]$.

Nodal status is central to the staging of oesophageal cancer, as it predicts survival $[1,7]$. Three confounding factors to describing nodal status need to be addressed in the setting of stenotic lesions: (a) dispute over the accuracy of endoscopic morphology alone in ascribing involvement [8]; (b) lack of a clear definition of what a coeliac node is or represents [9-11]; and extrapolating from this, (c) deficiency of the TNM staging system in respect of what is truly a local node and what is metastatic $[12,13]$. The presence of micrometastases in pN0 R0-resections ( $30 \%$ of cases) remains a joker in the pack [14].

To start at the beginning: the purpose of staging is to triage to appropriate therapy. There is an absolute need to know whether the lesion is not resectable for reasons of local spread (i.e T4 or not) or distant disease. There is a qualified need to know whether local lymphatic spread has occurred.

\section{Endosonography}

The problem: standard echoendoscopes are stiff and bulky, and tumour dilatation is not without risk. Initial studies reported worryingly high perforation rates $[15,16]$. More recent figures are considerably better but are not a true reflection of the risks experienced in a wider setting [17-20]. It should be remembered that tumour perforation has a dramatic impact on survival [20].

The combination of sequential dilation and passage of a standard echoendoscope overcomes these difficulties but the risks are higher. The risks associated with oesophageal tumour dilation although less pronounced than previously thought, are not negligible. A prospective audit reported a perforation rate of $6.4 \%$ following dilation and/or intubation of malignant strictures compared to $1.1 \%$ following dilation of benign strictures [21]. Strict adherence to a graded stepwise dilation protocol (for example, "rule of three") is advocated for safety, but this often means a second or third dilation session [22]. In addition to the risk and inconvenience to the patient, there are also financial implications for this approach both in terms of additional procedures and disposables. Furthermore, even with this approach, complete staging after dilatation might only be achieved in $62 \%$ of cases. (23) A final, important point is that the accuracy of EUS staging following dilatation might be poor, though this was reported in an "early" paper (1995) [15].

Approximately $55 \%$ of patients present with dysphagia, though this is not a reliable predictor of being unable to pass a standard echoendoscope [24]. There is a wide variation geographically in the proportion of those found to have stenotic lesions ranging from $25 \%$ (USA) to $73 \%$ (India) [15,25]. Approximately one-third 
of patients from Western countries with oesophageal cancer have stenoses at presentation significant enough to prevent the passage of a standard echoendoscope $[26,27]$.

Before discussing the options for dealing with non-traversable lesions, it is important to consider what information can be gleaned from an incomplete study. Stricturing tumours are rarely less than T3 and positive nodes might be expected in $77 \%-81 \%$ of these $[25,28,29]$. The lymphatics of the upper two-thirds of the oesophagus drain in a cephalad direction [30]. Sixty percent of involved nodes will be found proximal or level with the tumour, $25 \%$ being unreachable distal, yet local, nodes with a further $4.5 \%$ being located within $1 \mathrm{~cm}$ of the coeliac artery [31]. Applying reductionist logic, the staging problem presented by strictures is limited to relatively few cases, particularly taking into account those unfit for surgery (20\%), if neo-adjuvant chemotherapy is given to all operable tumours and if coeliac nodes might be considered local to junctional tumours [32,33].

There are six options for non-traversable malignant strictures: dilation of the stenosis to allow for passage by a standard echoendoscope, use of a catheter ultrasound probe, use of the Olympus MH908 oesophagoprobe, reliance on cross sectional imaging such as CT and positron emission tomography (PET), diagnostic surgery, or, a combination of methods. But, whichever approach is taken, it ought to be done at a specialist centre [34].

Miniprobes (catheter probes) are generally of high frequency $(12 \mathrm{MHz}-30 \mathrm{MHz})$, excepting the Fujinon $7.5 \mathrm{MHz}$ back-loaded probe (PL-2226B-7.5). The resulting lack of penetration offsets the advantage of small size; although miniprobe sonography can be as accurate as standard echoendosonography, these instruments are not adequate for the staging of large tumours or distant nodes $[25,35]$.

The Olympus (MH908) $7.9 \mathrm{~mm}$ non-optical, wire-guided, 7.5MHz, oesophagoprobe showed promising results in small studies [3638]. Later, larger series (reported in abstract) show this instrument to be a very powerful tool, permitting the complete staging (by morphology) of $95 \%$ of cases without the need for dilatation. $(25,31)$ Questions have been raised over the ability of the MH908 to adequately inspect the coeliac trunk on account of restricted tip-deflection, but this worry is not born out in practice $[31,35]$.

Intuitively, it would be reasonable to reserve the oesophagoprobe for those in whom a standard echoendoscope failed to pass. However, as problematic strictures cannot be predicted with any certainty from prior clinical questioning and as EUS equipment may be limited, the use of oesophagoprobe from the outset will improve the staging success and decrease the need for dilation. It might be suggested that the MH908 is the instrument of choice for all oesophageal tumours.

But, what of coeliac nodes and the need to biopsy? This question can only be answered at a local level. There is probably a great difference in the number of lymph nodes to be found in a "normal" mediastinum between both geographic regions and races. It is likely that endemic diseases whether fungal (USA), tuberculosis (developing world) or sarcoid (Afro-Caribbean) lead to varying numbers of detectable nodes; a point noted in Indians under- going surgery for oesophageal cancer [40]. Anecdotal evidence from the UK (personal data) suggests that if a rounded node is found in a caucasian, in the presence of a tumour, it will almost certainly be positive. Similarly, our experience is that coeliac nodes (those within $1 \mathrm{~cm}$ of the coeliac trunk) are only found in $4.5 \%$ of cases, a lower figure than that reported by others $[40,41]$. Taking local conditions into account, application of modified EUS criteria could be applied to minimize the need for FNA [42]. In re-staging tumours following neoadjuvant chemotherapy, EUS-FNA might certainly offer clinically relevant information as non-biopsy FNA in this setting adds little to the information provided by CT [43]. This issue is dealt with elsewhere in this supplement.

\section{CT and PET}

Turning to cross-sectional imaging to help with the predicament of strictured lesions. Improvements in computed tomography and greater experience with positron emission tomography (PET) have opened up the possibility of high resolution, dynamic images with the potential for virtual endoscopy. Unfortunately, this bright bauble of imaging tarnishes rapidly.

Leaving aside structural methods of staging and turning to dynamic imaging. Positron Emission Tomography is not tumour specific as benign tissue may accumulate tracer; the commonly used 18F-fluoro-deoxyglucose (FDG), however, is superior to other substrates [44,45]. Early studies showed PET to identify local disease $[46,47]$ though imperfectly $[46,48,49]$ as well as distant metastases [46-50]. Importantly, the histology of the tumour does not confound PET results [51].

Reviewing comparative studies with CT, PET does not identify all primary tumours [52-59]; it does not identify all involved nodes [sensitivity: $30 \%-80 \%$, median $45 \%$; specificity $82 \%$ $100 \%$, median $90 \%$ and accuracy $48 \%-93 \%$, median $80 \%$ ] $[47,48,52,46,65,53,54,62,63,61,60,51,64,58]$ and nor does it identify all distant metstases [sensitivity 38\%-88\%, median $64 \%$; specificity $89 \%-93 \%$, median $90 \%$ and accuracy $74 \%$ $91 \%][47,48,50,52,54,57,58,61-64,66]$. But, PET certainly yields additional useful information to that provided by $\mathrm{CT}$ $[47,48,51,52,54,58,64,66,67]$. As one might expect with a dynamic modality, PET demonstrates superior specificity but lower sensitivity than EUS for the identification of loco-regional nodes $[54,57,64,68]$.

Technology gets better. Combined PET/CT holds promise for incremental improvement in staging accuracy. [69-71] But, initial reports evaluating multi-detector CT (with virtual endoscopy) show a persisting inferiority in accuracy to that obtained with PET [72].

The major drawbacks, impairing the accuracy of PET include: a halo effect from the primary tumour hotspot obscuring local nodes [46], a high rate of false-positive hilar node interpretations [63], a tendency to lower sensitivity for nodes in the mid/lower thorax as compared with those in the upper chest, neck or abdomen [55] and spatial/breathing artefact [70]. A false-positive rate of $15 \%$ is worrying yet, PET still outperforms EUS-FNA [73, 74]. 
In addition to staging information, the data yielded by PET such as degree of tracer uptake (standardized uptake value, SUV), has been shaken, poked and prodded to reveal prognostic information: an SUV greater than 3-4.5 may predict a less good outcome $[55,75]$ but, this is not universally reported $[76,77]$.

In the setting of neo-adjuvant chemo(radio)therapy, the dynamic nature of PET holds promise for guiding treatment. As might be expected, the burden of disease identified by PET (tumour length and number of positive nodes) and resultant upstaging correlate poorly with survival $[66,78]$. Early change in tumour 18 F-FDG uptake predicts a reduction in tumour size following completion of therapy [79]. In respect of pathological response, a drop in SUV, possibly from a high baseline $(>4)$ may correlate with favourable post-operative findings [55,80-82] and/or survival $[83,84]$. Again, not all authors are so positive $[85,86]$. A metaanalysis of the accuracy of PET, CT and EUS in assessing response to chemotherapy shows equivalence between PET and EUS, both being superior to CT [87].

Overall assessment of the clinical value of PET in the setting of oesophageal cancer shows benefit in terms of useful additional information and the prevention of unnecessary surgery $[51,52,60,60,88-90]$ although a medium sized trial $(n=56)$ rains somewhat on this parade [61]. In terms of cost, although the best approach might be PET combined with EUS-FNA, limiting investigations to CT and EUS-FNA might be the most cost effective [91]. Such models however, cannot address the difficulties presented by strictured lesions. So, where does that leave us? PET holds promise in the staging and re-staging of oesophageal tumours but, not as a free standing test.

\section{Other techniques}

Other methods to detect lymphatic spread of disease include the search for sentinel lymph nodes whether by cross-sectional or intra-operative lymphangiography $[92,93,84]$. It is not possible to place this approach in any algorithm from the information available.

\section{Towards an algorithm}

So, what to do with a stricturing tumour of the oesophagus or oesophago-gastric junction? There are three issues to addressed before imaging: firstly, ascertain the local disease "profile" of this carcinoma (might the majority of nodes, particularly those at the coeliac axis, be considered positive?); secondly, decide whether the patient is fit for surgery and thirdly, decide the criteria for offering neo-adjuvant chemotherapy and subsequent operability ("once T4, always T4"?, what if a coeliac node disappears with therapy? etc). Initial imaging triage should be with CT, or ideally PET/CT. If no disease spread is seen, then EUS using the Olympus oesophagoprobe followed by either acceptance of morphological evidence or graded-dilatation followed by EUS-FNA. In respect of residual strictures following neo-adjuvant chemotherapy, EUS-FNA is required if positive cytology will lead to a non-operable status.

\section{Competing interests: None}

\section{References}

${ }^{1}$ el Nakadi I, Houben JJ, Gay F, Closset J, Gelin M, Lambilliotte JP. Does oesophagectomy cure resectable oesophageal cancer? World J Surg 1993; 17: 760 - 764

${ }^{2}$ Rouvelas I, Zeng W, Lindblad M, Viklund P, Ye W, Lagergren J. Survival after surgery for oesophageal cancer: a population-based study. Lancet Oncol 2005; 6: 864-870

${ }^{3}$ Urschel JD, Vasan H, Blewett CJ. A meta-analysis of randomized controlled trilas that compare neo-adjuvant chemotherapy and surgery to surgery alone for resectable esophageal cancer. Am J Surg 2002; 183: $274-279$

${ }^{4}$ Agarwal B, Swisher S, Ajani J, Kelly K, Komaki RR, Putnam JBJr, AbuHamda E, Moltke KL, Walsh GL, Correa AM, Ho L, Liao Z, Lynch PM, Rice DC, Smythe WR, Stevens CW, Vaporiciyan AA, Yao J, Roth JA. Endoscopic ultrasound after preoperative chemoradiation can help identify patients who benefit maximally after surgical oesophageal resection. Am J Gastroenterol 2005; 100: 496-497

${ }^{5}$ Mariette C, Finzi L, Piessen G, Van Seuningen I, Triboulet JP. Esophageal carcinoma: prognostic differences between squamous cell carcinoma and adenocarcinoma. World J Surg 2005; 29: 39-45

${ }^{6}$ Yuasa N, Miyake H, Yamada T, Ebata T, Nimura Y, Hattori T. Clinicopathologic comparison of Siewert type II and III adenocarcinomas of the gastrooesophageal junction. World J Surg 2006; 30: 364-371

${ }^{7}$ Rice TW, Blackstone EH, Adelstein DJ, Zuccaro GJr, Vargo JJ, Goldblum JR, Rybicki LA, Murthy SC, Decamp MM. N1 esophageal carcinoma: the importance of staging and downstaging. J Thorac Cardiovasc Surg 2001; $121: 454-464$

${ }^{8}$ Eloubeidi MA. Routine EUS-guided FNA for preoperative nodal staging in patients with oesophageal carcinoma: is the juice worth the squeeze? Gastrointest Endosc 2006; 63: 212 - 214

${ }^{9}$ Christie NA, Rice TW, DeCamp MM, Goldblum JR, Adelstein DJ, Zucarro GJr, Rybicki LA, Blackstone EH. M1a/M1b esophageal carcinoma: clinical relevance.

${ }^{10}$ Frizzell B, Sinha D, Williams T, Reed CE, Sherman CA, Turrisi A. Influence of celiac axis lymph nodes in the definitive treatment of oesophageal cancer. Am J Clin Oncol 2003; 26: 215-220

11 Lerut T, Coosemans W, Decker G, De Leyn P, Moons J, Nafteux P, Van Raemdonck D. Extended surgery for cancer of the oesophagus and gastroesopahgeal junction. J Surg Res 2004; 117: 58-63

12 Rice TW, Blackstone EH, Rybicki LA Adelstein DJ, Murthy SC, Decamp MM Goldblum JR. Refining oesophageal cancer staging. J Thorac Cardiovasc Surg 2003; 125: 992 - 993

${ }^{13}$ Kunisaki C, Akiyama H, Nomura M, Matsuda G, Otsuka Y, Ono HA, Shimada $\mathrm{H}$. Developing an appropriate staging system for esophageal carcinoma. J Am Coll Surg 2005; 201: 884-890

${ }^{14}$ Heeren PA, Kelder W, Blodeel I, van Westreenen HL, Hollema, Plukker JT. prognostic value of nodal micrometastases in patients with cancer of the gastro-oesophageal junction. Eur J Surg Oncol 2005; 31: $270-$ 276

${ }^{15}$ Catalano MF, Van Dam J, Sivak MVJr. Malignant esophageal strictures: staging accuracy of endoscopic ultrasonography. Gastrointest Endosc 1995; 41: $535-539$

16 Van Dam J, Rice TW, Catalano MF, Kirby T, Sivak MVJr. High-grade malignant stricture is predictive of esophageal tumor stage: risks of endosonographic evaluation. Cancer 1993; 71: 2910-2917

17 Wallace MB, Hawes RH, Sahai AV, Van Velse A, Hoffman BJ. Dilation of malignant esophageal stenosis to allow EUS guided fine-needle aspiration: safety and effect on patient management. Gastrointest Endosc 2000; 51: 309-313

18 Pfau PR, Ginsberg GG, Lew RJ, Faigel DO, Smith DB, Kochman ML. Esophageal dilation for endosonographic evaluation of malignant esophageal strictures is safe and effective. Am J Gastroenterol 2000; 95: $2813-2815$

19 Kallimanis GE, Gupta PK, Al-Kawas FH, Tio LT, Benjamin SB, Bertagnolli ME et al. Endoscopic ultrasound for staging esophageal cancer, with or without dilation, is clinically important and safe. Gastrointest Endosc 1995; 41: $540-546$

20 Jethwa P, Lala A, Powell J, McConkey CC, Gillison EW, Spychal RT. A regional audit of iatrogenic perforation of tumours of the oesophagus and cardia. Aliment Pharmacol Ther 2005; 21: 479-484

${ }^{21}$ Quine MA, Bell GD, McCloy RF, Matthews HR. Prospective audit of perforation rates following upper gastrointestinal endoscopy in two regions of England. Br J Surg 1995; 82: 530-533 
${ }^{22}$ Langdon DF. The rule of three in oesophageal dilatation. Gastrointest Endosc 1997; 45: 111

${ }^{23}$ Vazquez-Sequeiros E, Wiersema MJ, Clain JE, Norton ID, Levy MJ, Romero Y, Salomao D, Dierkhising R. Impact of lymph node staging on therapy of oesophageal carcinoma. Gastroenterol 2003; 125: 1626 1635

${ }^{24}$ Schlansky B, Dimarino AJJr, Loren D, Infantolino A, Kowalski T, Cohen S. A survey of oesophageal cancer: pathology, stage, and clinical presentation. Aliment Pharmacol Ther 2006; 23: 587-589

${ }^{25}$ Dhir V, Mohandas KM, Mehta S, Shastri Y, Sharma S, Deshpande RK. Endoscopic ultrasound staging of stenotic oesophageal cancer: miniprobe, dilation, MH908 or helical computed tomography (CT)? Gastrointest Endosc 2002; 56: S108

${ }^{26}$ Dittler HJ, Siewert JR. Role of endoscopic ultrasonography in esophageal carcinoma. Endoscopy 1993; 25: 156-161

${ }^{27}$ Grimm H, Binmoeller KF, Hamper K, Koch J, Henne-Bruns D, Soehendra $\mathrm{N}$. Endosonography for the preoperative locoregional staging of esophageal and gastric cancer. Endoscopy 1993; 25: 224-230

${ }^{28}$ Rice TW, Zucarro GJr, Adelstein DJ, Rybicki LA, Blackstone EH, Goldblum JR. Oesophageal carcinoma: depth of tumor invasion is predictive of regional lymph node status. Ann Thorac Surg 1998; 65: 787 792

${ }^{29}$ Koufuji K, Shirouzu K, Aoyagi K, Yano S, Miyagi M, Imaizumi T, Takeda J. Surgery and clinicopathological features of gastric adenocarcinoma involving the esophago-gastric junction. Kurume Med J 2005; 52: $73-79$

${ }^{30}$ Sharma A, Fidias P, Hayman LA, Loomis SL, Taber KH, Aquino SL. Patterns of lymphadenoathy in thoracic malignancies. Radiographics 2004; 24: 419-434

${ }^{31} \mathrm{Vu}$ C, Doig LA, Anderson S, Tsang S, Meenan J. Large series Western European experience with the Olympus MH908 slim-probe shows greater complete staging of oesophageal cancer without the need for dilatation. Gastrointest Endosc 2004; 59: AB213

32 Gockel I, Kneist W, Junginger T. Incurable oesophageal cancer: patterns of tumor spread and therapeutic consequences. World J Surg 2006; 30: 183 - 190

${ }^{33}$ Medical Research Council Working Party. Surgical resection with or without preoperative chemotherapy in oesophageal cancer: a randomised controlled trial. Lancet 2002; 359: 1727-1733

${ }^{34}$ van Vliet EP, Eijkemans MJ, Kuipers EJ, Hermans JJ, Steyberg EW, Tilanus HW, van der Gaast A, Siersma PD. A comparison between low volume referring regional centers and a high volume referral centre in quality of preoperative metastasis detection in oesophageal carcinoma. Am J Gastroenterol 2006; 101: 234-242

${ }^{35}$ Menzel J, Hoepffner, Nottberg H, Schulz C, Senninger N, Domschke W. Preoperative staging of esophageal carcinoma: miniprobe sonography versus conventional endoscopic ultrasound in a prospectively histopathologically verified study. Endoscopy 1999; 31: $291-297$

${ }^{36}$ Binmoeller KF, Seifert H, Seitz U, Izbicki JR, Kida M, Soehendra N. Ultrasonic esophagoprobe for TNM staging of highly stenosing esophageal carcinoma. Gastrointest Endosc 1995; 41: 547 - 552

37 Mallery S, Van Dam J. Increased rate of complete EUS staging of patients with esophageal cancer using the non-optical, wire-guided echoendoscope. Gastrointest Endosc 1999; 50: 53-57

${ }^{38}$ Bowrey DJ, Clark GWB, Roberts SA, Maughan TS, Hawthorne AB, Williams GT $t$ al. Endosonographic staging of 100 consecutive patients with esophageal carcinoma: introduction of the 8-mm esophagoprobe. Diseases of the Esophagus 1999; 12: $258-263$

${ }^{39}$ Sharma D, Thakur A, Toppo S, Chandrakar SK. Lymph node counts in Indians in relation to lymphadenectomy for carcinoma of the oesophagus and stomach. Asian J Surg 2005; 28: $116-120$

40 Quint LE, Hepburn LM, Francis IR, Whyte RI, Orringer MB. Incidence and distribution of distant metastases from newly diagnosed esophageal carcinoma. Cancer 1995; 76: 1120-1125

41 Pfau PR, Ginsberg GG, Lew RJ, Brensinger CM, Kochman ML. EUS predictors of long-term survival in esophageal carcinoma. Gastrointest Endosc 2001; 53: 463-469

42 Vazquez-Sequeiros E, Levy MJ, Clain JE, Schwartz DA, Harewood GC, Salomao D, Wiersema MJ. Routine v's selective EUS-guided FNA approach for preoperative nodal staging of oesophageal carcinoma. Gastrointest Endosc 2006; 63: 204-211

${ }^{43}$ Mesenas S, Vu C, McStay M, Doig LA, Meenan J. Radial EUS for re-staging oesophageal cancer after neoadjuvant chemotherapy predicts survival but not resectability: a large resection controlled study. Gastrointest Endosc, 2006 (DDW 2006, In press)
${ }^{44}$ van Westreenen HL, Cobben DC, Jager PL, van Dullemen HM, Wesseling J, Elsinga PH, Plukker JT. Comparison of 18F-FLT PET and 18F-FDG PET in oesophageal cancer. J Nucl Med 2005; 46: 400-404

45 Jager PL, Que TH, Vaalburg W, Pruim J, Elsinga P, Plukker JT. Carbon-11 choline or FDG-PET for staging of oesophageal cancer? Eur J Nucl Med 2001; 28: $1845-1849$

${ }^{46}$ Rankin SC, Taylor H, Cook GJR, Mason R. Computed tomography and positron emission tomography in the pre-operative staging of oesophageal carcinoma. Clinical Radiol 1998; 53: 659-665

${ }^{47}$ Flanagan FL, Dehdashti F, Siegel BA, Trask DD, Sundaresan SR, Patterson GA, Cooper JD. Staging of oesophageal cancer with 18F-fluorodeoxyglucose positron emission tomography. Am J Roentgenol 1997; 168: $417-424$

${ }^{48}$ Luketich JD, Schauer PR, Meltzer CC, landreneau RJ, Urso GK, Townsend DW, Ferson PF, Keenan RJ, Belani CP. Role of positron emission tomography in staging oesophageal cancer. Ann Thorac Surg 1997; 64: $765-769$

${ }^{49}$ Meltzer CC, Luketich JD, Friedman D, Charron M, Strollo D, Meehan M, Urso GK, Dachille MA, Townsend DW. Whole-body FDG positron emission tomography imaging for staging esopahgeal cancer, comparison with computed tomography. Clin Nucl Med 2000; 25: 882 - 887

${ }^{50}$ Luketich JD, Friedman DM, Weigel TL, Meehan MA, Keenan RJ, Townsend DW, Meltzer CC. Evaluation of distant metastases in oesophageal cancer: 100 consecutive positron emission tomography scans. Ann Thorac Surg 1999; 68: $1133-1136$

51 Yeung HW, Macapinlac HA, Mazumdar M, Bains M, Finn RD, Larson SM. FDG-PET in oesophageal cancer. Incremental value over computed tomography. Clin Positron Imaging 1999; 2: 255 - 260

52 Kole AC, Plukker JT, Nieweg OE, Vaalburg W. Positron emission tomography for staging oesophageal and gastrooesophageal malignancy. $\mathrm{Br} J$ Cancer 1998; 78: $521-527$

${ }^{53}$ Montravers F, Grahek D, Kerrou K, de Beco V, Younsi N, Barrier A, LKacaine F, Huguier M, Talbot JN. 14.FDG CDET (2D dual-head coincidence gamma camera) in the primary staging of oesophageal cancer. Histopathological correlation. Clin Positron Imaging 2000; 3: 168

${ }^{54}$ Flamen P, Lerut A, Van Cutsem E, De Wever W, Peeters M, Stroobants S, Dupont P, Bormans G, Hiele M, De Leyn P, Van Raemdonck D, Coosemans W, Ectors N, Haustermans K, Martelmans L. Utility of positron emission tomography for the staging of patients with potentially operable oesophageal carcinoma. J Clin Oncol 2000; 18: 3202 - 3210

${ }^{55}$ Kato H, Kuwano H, Nakajima M, Miyazaki T, Yoshikawa M, Ojima $\mathrm{H}$, Tsujada K, Oriuchi N, Inoue T, Endo K. Comparison between positron emission tomography and computed tomography in the assessment of oesophageal carcinoma. Cancer 2002; 94: 921 - 928

${ }^{56}$ Yeung HW, Macapinlac HA, Mazumdar M, Bains M, Finn RD, Larson SM. FDG-PET in oesophageal cancer. Incremental value over computed tomography. Clin Positron Imaging 1999; 2: 255 - 260

${ }^{57}$ Rasanen JV, Sihvo EI, Knuuti MJ, Minn HR, Luostarinen ME, Laippala P, Viljanen T, Salo JA. Prospective analysis of accuracy of positron emission tomography, computed tomography and endoscopic ultrasonography in staging of adenocarcinoma of the oesophagus and the esophagogastric junction. Ann Surg Oncol 2003; 10: 954-960

${ }^{58}$ Kato H, Miyazaki T, Nakajima M, Takita J, Kimura H, Faried A, Sohda M, Fukai Y, Masuda N, Fukuchi M, Manda R, Ojima H, Tsukada K, Oriuchi $\mathrm{N}$, Endo K. The incremental effect of positron emission tomography on diagnostic accuracy in the initial staging of oesophageal carcinoma. Cancer 2005; 103: $148-156$

${ }^{59}$ Meenan J, Vu C, Rankin S, Harper P. A prospective, blinded trial comparing the accuracy of PET, EUS and CT with resection pathology in the staging of oesophageal cancer following neo-adjuvant chemotherapy. Gastrointest Endosc 2004; 59: AB214

${ }^{60}$ Sihvo EI, Rasanen JV, Knuuti MJ, Minn HR, Luostarinen ME, Viljananen, Farkkila MA, Salo JA. Adenocarcinoma of the oesophagus and the esophagogastric junction: positron emission tomography improves staging and prediction of survival in distant but not in loco-regional disease. Gastrointest Surg 2004; 8: 988 - 996

${ }^{61}$ Kneist W, Schreckenberger M, Bartenstein P, Grunwald F, Oberholzer $\mathrm{K}$, Junginger T. Positron emission tomography for staging oesophageal cancer: does it lead to a different therapeutic approach? World J Surg 2003; 27: $1105-1112$

${ }^{62}$ Kneist W, Schreckenberger M, Bartenstein P, Menzel C, Oberholzer K, Junginger T. Prospective evaluation of positron emission tomography in the preoperative staging of oesophageal cancer. Arch Surg 2004; 139: $1043-1049$ 
${ }^{63}$ Yoon YC, Lee KS, Shim YM, Kim BT, Kim K, Kim TS. Metastasis to regional lymph nodes in patients with esopahgeal squamous cell carcinoma: CT versus FDG PET for presurgical detection. A prospective study. Radiology 2003; 227: 764-770

${ }^{64}$ Lowe VJ, Booya F, Fletcher JG, Nathan N, Jensen E, Mullan B, Rohren E, Wiersema MJ, Vazquez_Sequeiros E, Murray JA, Allen MS, Levy MJ, Clain JE. Comparion of positron emission tomography, computed tomography and endoscopis ultrasound in the initial staging of patients with oesophageal cancer. Mol Imaging Biol 2005; 7: 422-430

${ }^{65}$ McAteer D, Wallis F, Couper G, Norton M, Welch A, Bruce D, Park K, Nicolson M, Gilbert FJ, Sharp P. Evaluation of 18F FDG positron emission tomography in gastric and oesophageal carcinoma. Br J Radiol 1999; 72: 525-529

${ }^{66}$ Blackstock AW, Farmer MR, Lovato J, Mishra G, Melin SA, Oaks T, Aklilu $\mathrm{M}$, Clark PB, Levine EA. A prospective evaluation of the impact of 18-Ffluoro-deoxy-D-glucose positron emission tomography staging on survival for patients with locally advanced oesophageal cancer. Int J Radiat Oncol Biol Phys 2006; 64: 455-460

${ }^{67}$ Rasanen JV, Sihvo EI, Knuuti MJ, Minn HR, Luostarinen ME, Laippala P, Viljanen T, Salo JA. Propsective analyisi of accuracy of positron emission tomography, computed tomography and emdoscopic ultrasound in staging of adenocarcinoma of the oesophagus and esophagogastric junction. Ann Surg Oncol 2003; 10: $954-960$

68 Konski A, Doss M, Milestone B, Haluszka O, Hanlon A, Freedman G, Adler L. The integration of 18-fluoro-deoxy-glucose positron emission tomography and endoscopic ultrasound in the treatment planning process for oesophageal carcinoma. Int J Radiat Oncol Biol Phys 2005; 61: $1123-1128$

${ }^{69}$ Bar-Shalom R, Guralnik L, Tsalic M, Leiderman M, Frenkel A, Gaitini D, Ben-Nun A, Keidat Z, Israel O. The additional value of PET/CT over PET in FDG imaging of oesophageal cancer. Eur J Nucl Med Mol Imaging 2005; 32: $918-924$

70 Pan T, Mawlawi O, Nehmeh SA, Erdi YE, Luo D, Liu HH, Castollo R, Mohan R, Liao Z, Macapinlac HA. Attenuation correction of PET images with respiration-averaged CT images in PET/CT. J Nucl Med 2005; 46: $1481-1487$

${ }^{71}$ Moureau-Zabotto L, Touboul E, Lerouge D, Deniaud-Alexandre E, Grahek D, Foulquier JN, Petegnief Y, Gres B, El Balaa H, Kerrou K, Montravers F, Keraudy K, Tiret E, Gendre JP, Grange JD, Houry S, Talbot JN. Impact of CT and 18F-deoxyglucose positron emission tomography image fusion for conformal radiotherapy in oesophageal carcinoma. Int J Radiat Oncol Biol Phys 2005; 63: 340-345

72 Onbas O, Eroglu A, Kantarci M, Polat P, Alper F, Karaoglanoglu N, Okur A. Preoperative staging of oesophageal carcinoma with multidetector CT and virtual endoscopy. Eur J Radiol 2006; 57: 90-95

73 van Westreenen HL, Heeren PA, Jager PL, van Dullemen HM, Groen H, Plukker JT. Pitfalls of positive findings in staging esopahgeal cancer with F-18-fluorodeoxyglucose positron emission tomography. Ann Surg Oncol 2003; 10: $1100-1105$

${ }^{74}$ Cerfolio RJ, Bryant AS, Ohja B, Bartolucci AA, Eloubeidi MA. The accuracy of endoscopic ultrasonography with fine needle aspiration, integrated positron emission tomography with computed tomography and computed tomography in restaging patients with esophgaeal cancer after neoadjuvant chemoradiotherapy. J Thorac Cardiovasc Surg 2005; 129: 1232 - 1241

75 Rizk N, Downey RJ, Akhurst T, Gonen M, Bains MS, Larson S, Rusch V. Preoperative 18[F]-fluorodeoxyglucose positron emission tomography standardized uptake values predict survival after oesophageal adenocarcinoma resection. Ann Thorac Surg 2006; 81: 1076- 1081

${ }^{76}$ Hong D, Lunagomez S, Kim EE, Lee JH, Bresalier RS, Swisher SG, Wu TT, Morris J, Liao Z, Lomaki R, Ajani JA. Value of baseline positron emission tomography for predicting overall survival in patients with nonmetastatic oesophageal or gastroesophageal junction carcinoma. Cancer 2005; 104: $1620-1626$

77 Stahl A, Stollfuss J, Ott K, Wieder H, Fink U, Schwaiger M, Weber WA. FDG PET and CT in locally advanced adenocarcinomas of the distal oesophagus. Clinical relevance of a discordant PET finding. Nuklearmedizin 2005; 44: 249-255

${ }^{78}$ Choi JY, Jang HJ, Shim YM, Kim K, Lee KS, Lee KH, Choi Y, Choe YS, Kim BT. 18F-FDG PET in patients with oesophageal squamous cell carcinoma undergoing curative surgery: prognostic implications. J Nucl Med 2004; 45: $1843-1850$
79 Wieder HA, Beer AJ, Lordick F, Ott K, Fischer M, Rummeny EJ, Ziegler S, Siewer JR, Schwaiger, Weber WA. Comparison of changes in tumor metabolic activity and tumor size during chemotherapy of adenocarcinomas of the esophagogastric junction. J Nucl Med 2005; 46: 2029 2034

${ }^{80}$ Song SY, Kim JH, Ryu JS, Lee GH, Kim SB, Park SI, Song SY, Cho KJ, Ahn SD, Lee SW, Shin SS, Choi EK. FDG-PET in the prediction of pathologic response after neoadjuvant chemoradiotherapy in locally advanced, resectable oesophageal cancer. Int J radiat Oncol Biol Phys 2005; 63: $1052-1059$

81 Brucher BL, Weber W, Bauer M, Fink U, Avril N, Stein HJ, Werner M, Zimmerman F, Siewert JR, Schwaiger M. Neoadjuvant therapy of oesophageal squamous cell carcinoma: response evaluation by positron emission tomography. Ann Surg 2001; 233: 300-309

82 Swisher SG, Erasmus J, Maish M, Correa AM, Macapinlac H, Ajani JA, Cox JD, Komaki RR, Hong D, Lee HK, Putnam JBJr, Rice DC, Smythe WR, Thai L, Vaporciyan AA, Walsh GL, Wu TT, Roth JA. 2-fluoro-2-deoxy-D-glucose positron emission tomography imaging is predictive of pathologic response and survival after preoperative chemoradiation in patients with esopahgeal carcinoma. Cancer 2004; 101: 1776-1785

${ }^{83}$ Swisher SG, Maish M, Erasmus J, Correa AM, Ajani JA, Bresalier R, Komaki R, Macapinlac H, Munden RF, Putnam JBJr, Rice DC, Smythe WR, Vaporciyan AA, Walsh GL, Wu TT, Roth JA. Utility of PET, CT and EUS to identify pathologic responders in esophageal cancer. Ann Thorac Surg 2004; 78: $1152-1160$

${ }^{84}$ Downey RJ, Akhurst T, Ilson D, Ginsberg R, Bains MS, Gonen M, Koong H, Gollub M, Minsky BD, Zakowski M, Turnbull A, Larson SM, Rusch Y. Whole body 18FDG-PET and the response of esopahgeal cancer to induction therapy: results of a prospective trial. J Clin Oncol 2003; 21: $428-432$

${ }^{85}$ Brink L, Hentschel M, Bley TA, Walch A, Mix M, Klemaier M, Moser E, Imdahl A. Effects of neo-adjuvant radio-chemotherapy on 18F-FDGPET in oesophageal carcinoma. Eur J Surg Oncol 2004; 30: 544-550

${ }^{86}$ Arslan N, Miller TR, Dehdashti F, Battafarano RJ, Siegel BA. Evaluation of response to neoadjuvant therapy by quantitive 2-deoxy-2-[18F]fluoro-D-glucose with positron emission tomography in patients with oesophageal cancer. Mol Imaging Biol 2002; 4: 310-310

87 Westerterp M, van Westreenen HL, Hoekstra OS, Stoker J, Fockens P, Jager Pl, Van Eck-Smit BLF, Plukker JT, van Lanschot JB, Sloof GW. Oesophageal cancer: CT, Endoscopic US and FDG PET for assessment of response to neoadjuvant therapy- systemic review. Radiology 2005; 236: $841-851$

${ }^{88}$ Duong CP, Demitriou H, Weih L, Thompson A, Williams D, Thomas RJ, Hicks RJ. Significant clinical impact and prognostic stratification provided by FDG-PET in the staging of oesophageal cancer. Eur J Nucl Med Mol Imaging 2006; 10: 1-11

${ }^{89}$ Imdahl A, Hentschel M, Kleimaier M, Hopt UT, Brink L. Impact of FDGPET for staging of oesophageal cancer. Langenbecks Arch Surg 2004; 398: $283-288$

90 van Westreenen HL, Heeren PA, van Dullemen HM, van der Jagt KJ, Jager PL, Groen H, Plukker JT. Positron emission tomography with F-18fluorodeoxyglucose in a combined staging strategy of oesophageal cancer prevents unnecessary surgical explorations. J Gastrointest Surg 2005; 8: 54-61

${ }^{91}$ Wallace MB, Nietert PJ, Earle C, Krasna MJ, Hawes RH, Hoffman BJ, Reed CE. An analysis of mutliple staging management strategies for carcinoma of the oesophagus: computed tomography, endoscopic ultrasound, positron emission tomography and thoracic/laparoscopy. Ann Thorac Surg 2002; 74: 1026-1032

${ }^{92}$ Hayashi H, Tangoku A, Suga K, Shimizu K, Ueda K, Yoshino S, Abe T, Sato T, Matsunaga N, Oka M. Ct lymphography-navigated sentinel lymph node biopsy in patients with superficial oesophageal cancer. Surgery 2006; 139: 225-235

${ }^{93}$ Kitagawa Y, Fujii H, Mukai M, Kubo A, Kitajima M. Sentinel lymph node mapping in oesophageal and gastric cancer. Cancer Treat Res 2005; 127: $123-139$

${ }^{94}$ Cense HA, Sloof GW, Klaase JM, Bergman JJ, van Hemert FJ, Fockens P, van Lanschot JJ. Lymphatic drainage routes of the gastric cardia visulaized by lymphoscintigraphy. J Nucl Med 2004; 45: 247-252 